\title{
TEMPERATURE MEASUREMENT OF ICE AND WATER SURFACES IN THE NORTH WATER AREA USING AN AIRBORNE RADIATION THERMOMETER
}

\author{
By F. Müller, H. Blatter and G. Kappenberger \\ (Geographisches Institut, Eidgenössische Technische Hochschule, Zürich, Switzerland and \\ McGill University, Montreal, Quebec, Canada)
}

\begin{abstract}
Aвstract. Ice and water surface temperatures were measured with an airborne radiation thermometer PRT-5 over the North Water polynya during three missions between late winter and early summer 1974 . Error corrections, problems of data analyses and mapping are discussed. Attempts are made to relate the main types of sea ice to temperature ranges, which then are used in conjunction with satellite pictures to produce surface temperature maps.

RÉsumé. Deterinination des températures de surface de la glace et de l'eau dans la région de la "North Water"avec l'aide d'un t'iermomètre a radiation installé dans un avion. Trois missions ont été volées entre fin mars et début juin 1974 dans la région de la "North Water polynia" pour mesurer les températures de surface de la glace et de l'eau avec l'aide d'un thermomètre à radiation installé dans un avion. Les corrections des erreurs ainsi que les problèmes de l'analyse et de la cartographie sont discutés. On a essayé d'établir la relation des types de glace les plus répandus avec la température et d'employer ces résultats en conjunction avec les images de satellites pour la cartographie des températures de surface.

Zusammenfassung. Temperaturmessungen von Eis- und Wasseroberflächen in dem ",North Water" mit Hilfe eines in einem Flugzeug monitierten Infrarot Thermometers. Zwischen Spätwinter und Frühsommer 1974 wurden in drei Operationen über der North Water Tümpel Temperaturmessungen von Eis- und Wasseroberflächen durchgeführt mit Hilfe eines in einem Flugzeug montierten PRT-5 Infrarot Thermometers. Fehlerkorrekturen, Probleme der Auswertung und Kartierung werden diskutiert. Es wurde versucht, die häufigsten Eistypen mit ihren Temperaturen in Bezi zhung zu bringen, was zusammen mit Satellitenbildern für die Kartierung der Oberflächentemperatur benützt wurde.
\end{abstract}

\section{INTRODUCTION AND OPERATIONAL ARRANGEMENTS}

Within the framework of the North Water Project, climatological and glaciological observations in the northern part of Baffin Bay, between Greenland and Ellesmere Island, were carried out together with studies of the development of various types of floating ice and the associated surface temperatures throughout the seasons. The latter provides the lower boundary input for a meso-scale thermodynamic model of the atmosphere over this large polynya (Müller and others, 1973; Ohmura, 1972).

The surface temperature was measured on a zig-zag track over the area on $30 / 3 \mathrm{I}$ March, 22 April, and 8 June with an airborne Barnes PRT-5 infrared radiation thermometer, connected with a Super-8 movie camera filming a strip-picture of the measured profiles; the two instruments operated vertically through a hatch in the bottom of the plane. The radiometer was equipped with a $20^{\circ}$ field of view, thus providing a target with a diameter of $100 \mathrm{~m}$ for a flight level of $300 \mathrm{~m}$. The equipment was mounted in a Beechcraft, the air speed of which averaged $220 \mathrm{~km} / \mathrm{h}$.

As the necessary corrections are strongly dependent on the temperature of the air between the target and the plane, the readings from a thermistor, mounted outside the aircraft, were recorded together with the PRT-5 measurements on a HP 7100 BM two-channel chart recorder, though some technical difficulties were encountered with this. Electric pulses given by the camera every fourth frame facilitate relating the temperature records with the pictures, and thus with sea-ice types.

The synoptic and radiosonde data and some ground observations collected at the three manned North Water research stations (Coburg Island, Carey Øer, and Cape Herschel) have been used to test and evaluate the PRT -5 measurements. The radiation thermometer flights were performed as near to the dates of the satellite (ERTS-I) overpasses as weather and logistics permitted. 


\section{Corrections}

Several factors necessitate the application of corrections. Water and ice deviate from an ideal black body causing the spectral emmissivity to be smaller than unity. There is infrared absorption and emission by the water vapour of the air layer between the sea-ice surface and the airborne radiometer. Reflected infrared sky radiation may also affect the sensor readings. The magnitude of these corrections is mainly dependent on the surface temperature and the temperature and humidity of the air (Lorenz, I 968). Using the narrow spectral range 9.5 to I I. $5 \mu \mathrm{m}$, the cumulative error is reduced to about I deg. The spectral sensitivity of the instrument used, the spectral reflectivity $\mathrm{I}-\epsilon$ of water and ice surfaces, and the spectral absorption coefficient of water vapour are shown in Figures I, 2 and 3, and are based on Haltiner and Martin (1957, p. 8I ff.) and Kondratyev (1965, p. I I 3 ff.).

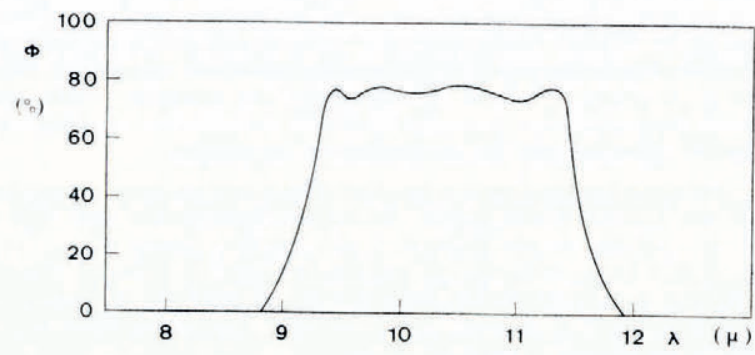

Fig. I. Spectral sensitivity $\phi$ of the PRT-5 radiometer.

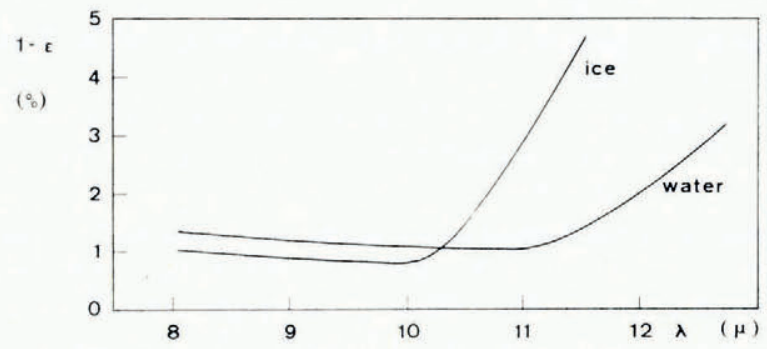

Fig. 2. Spectral reflectivity $I-\epsilon$ of water and ice surfaces.

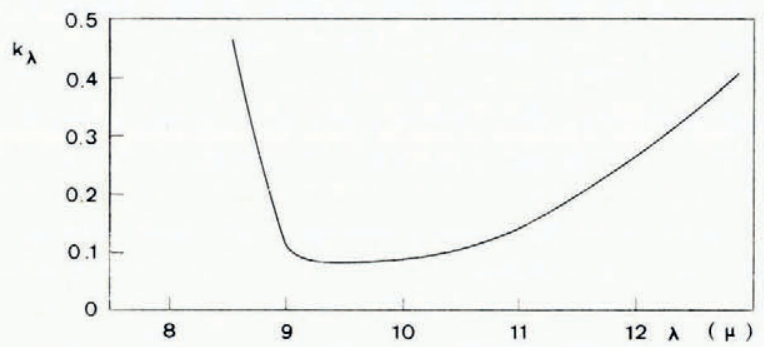

Fig. 3. Spectral absorption coefficient $k$ of water vapour. 

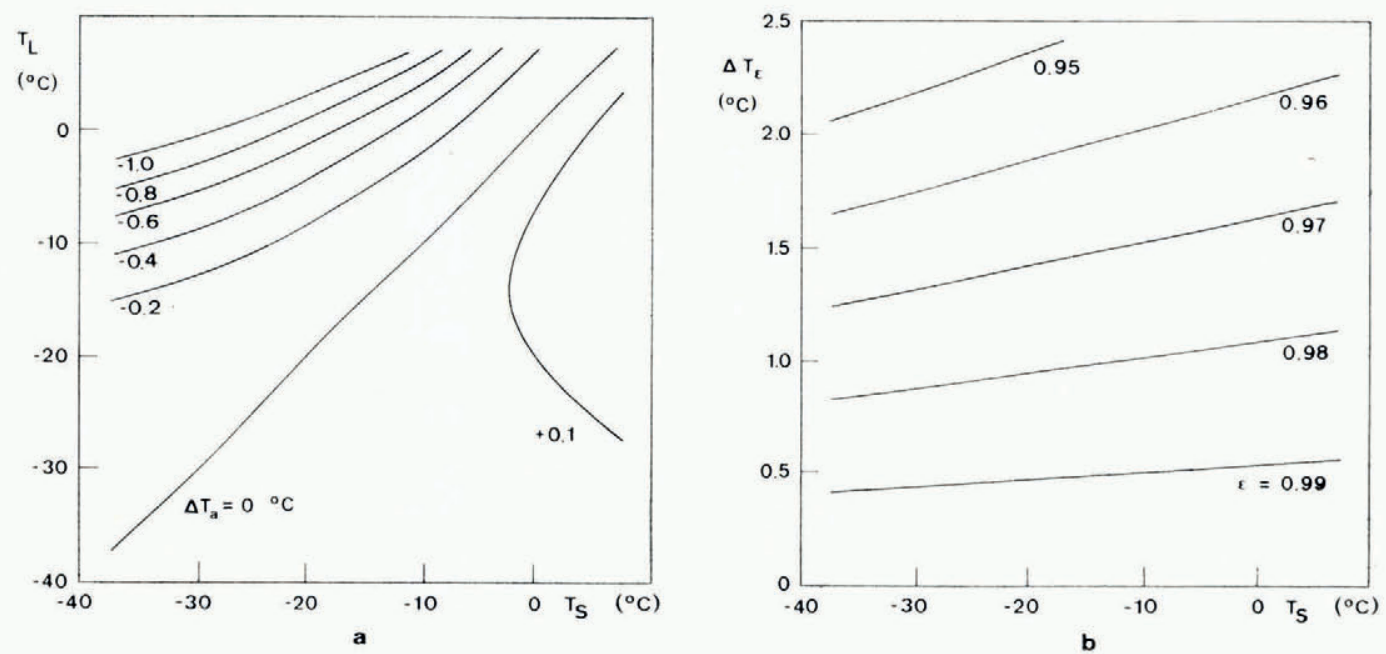

Fig. 4. Correction of the surface temperature measurement due to the influence of the water-vapour layer (a) and due to the deviation of the water and ice surfaces from an ideal black body $(b)$.

The correction nomograms for the two main errors (Figs. $4 \mathrm{a}$ and $4 \mathrm{~b}$ ) are based on the following approximate calculations: The temperature correction $\Delta T_{\varepsilon}$ due to the deviation of ice and water from an ideal black body is given by

$$
\Delta T_{\epsilon}=(\mathrm{r}-\bar{\epsilon}) \frac{E\left(T_{\mathrm{s}}\right)}{\mathrm{d} E\left(T_{\mathrm{s}}\right) / \mathrm{d} T}
$$

and the correction $\Delta T_{\mathrm{a}}$ resulting from the absorption and emission of a water-vapour layer of optical depth $\Delta u$ [units $\left.\mathrm{g} / \mathrm{cm}^{2}\right]$ in the air layer between aircraft and ground is obtained from (Haltiner and Martin, 1957)

$$
\Delta T_{\mathrm{a}}=\frac{\bar{k} \cdot \Delta u\left(E\left(T_{\mathrm{s}}\right)-E\left(T_{\mathrm{L}}\right)\right)}{\mathrm{d} E\left(T_{\mathrm{s}}\right) / \mathrm{d} T}
$$

where $\bar{\epsilon}$ is the average emissivity of the surface in the spectral range used, $\bar{k}$ the average absorption coefficient of water vapour in the same spectral range, and $E\left(T_{\mathrm{L}}\right)$ and $E\left(T_{\mathrm{s}}\right)$ the energies of black-body radiation at air temperature $T_{\mathrm{L}}$ and surface temperature $T_{\mathrm{s}}$. The relative humidity is assumed to be $100 \%$ and the air temperature constant for the whole air layer.

For clear sky, the influence of the reflected sky radiation was found to be negligible, while that for high cirrus clouds of 5/10 coverage was estimated to be smaller than $-0.3 \mathrm{deg}$.

\section{TEGHNique of DATA ANALYSIS AND RESUlts}

Though the first flight was carried out on two consecutive days, 30 and 31 March 1974 , the profiles fitted together well; the weather remained unchanged. Unfortunately, large fog banks persisting along the east side of the North Water prevented us obtaining useful data from that area. During the second flight (22 April) weather conditions north of lat. $76^{\circ} \mathrm{N}$. were ideal, while on the occasion of the third flight ( $8 \mathrm{June})$, strong winds over the entire area made accurate navigation difficult. By 8 June, warm air masses and increased radiation had warmed up most of the sea-ice surfaces to the melting point.

In Figure 5 a transcribed and corrected sample of a radiation temperature record is given together with the corresponding photograph strip showing some of the main sea-ice types in the North Water area. 


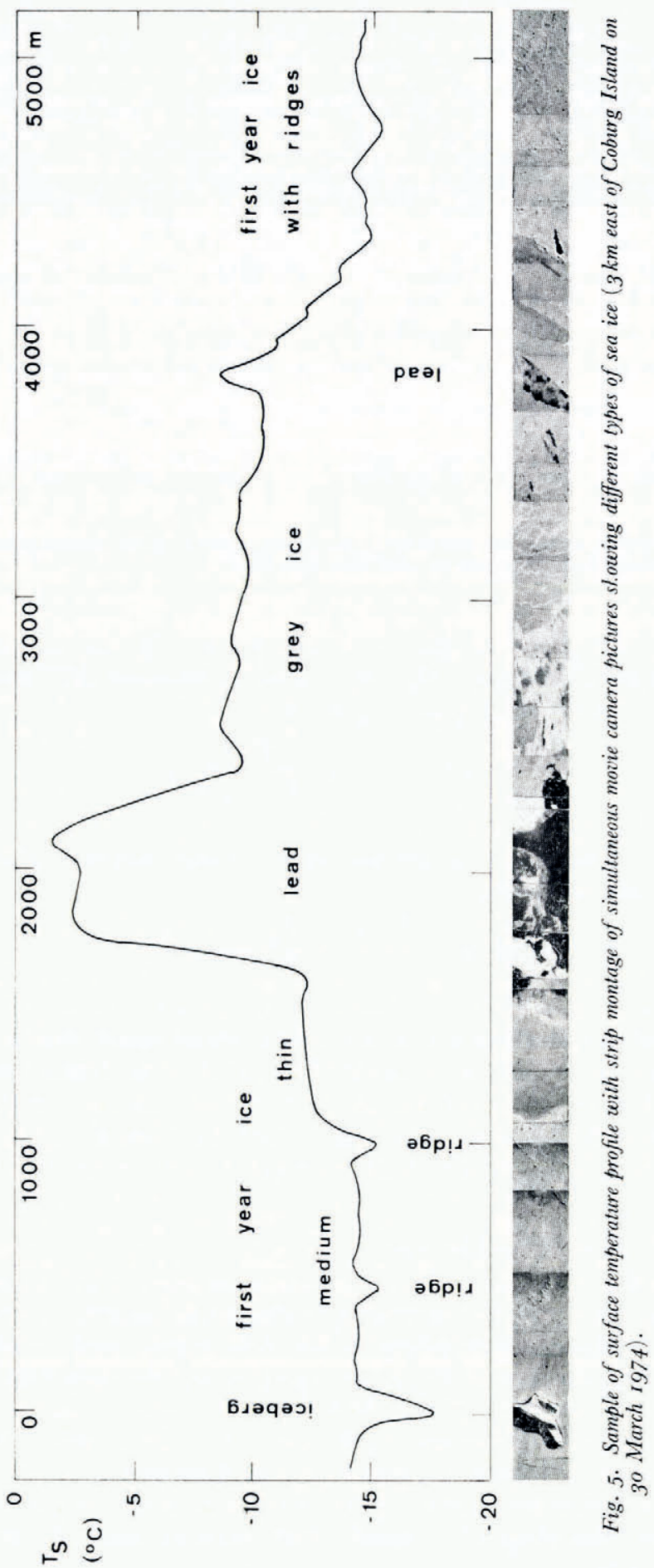


The basic unit used for analysis on the analogue record corresponds to a ground element of $200 \mathrm{~m}$ along the flight path. These resolution elements were first averaged over $10 \mathrm{~km}$ intervals, then the necessary corrections were applied and the sequences plotted against the distance from the point of origin of each profile. Figures 6 to ro present some of these $10 \mathrm{~km}$ step profiles. Mainly for navigational reasons (direct sighting on landmarks, radar, and sun compass) it was not possible to relocate the flight paths of the profiles in the same place on the three different dates. The flight paths are shown on Figures I I and I2. Before the profiles could be utilized for mapping of the surface temperature distribution they had to be smoothed

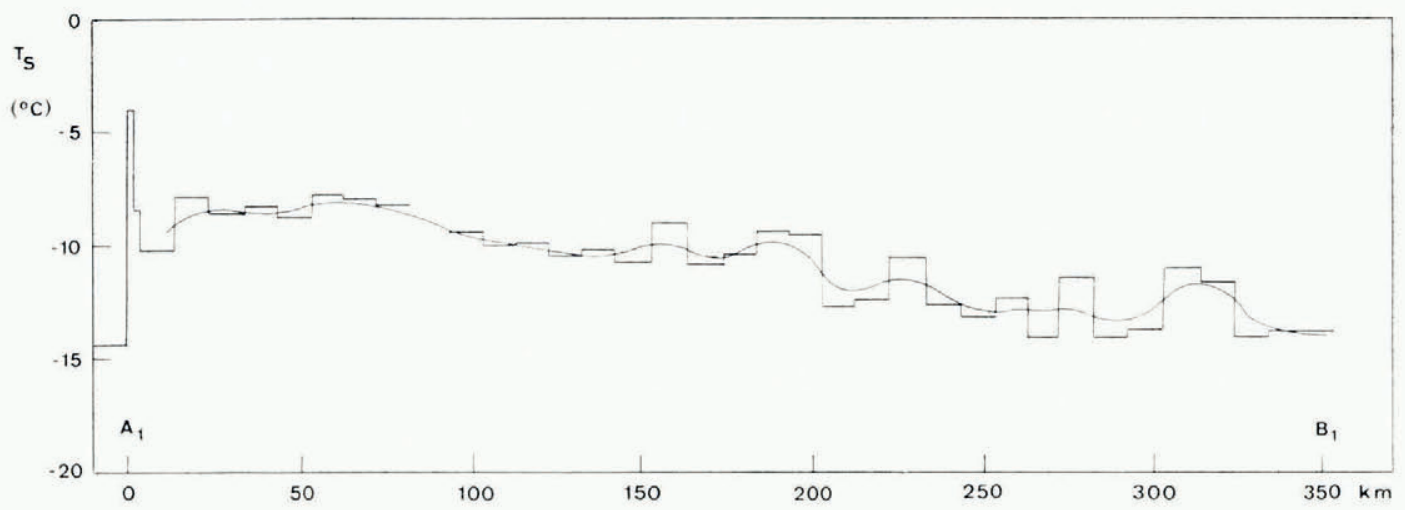

Fig. 6. North-south profile zo March 1974.

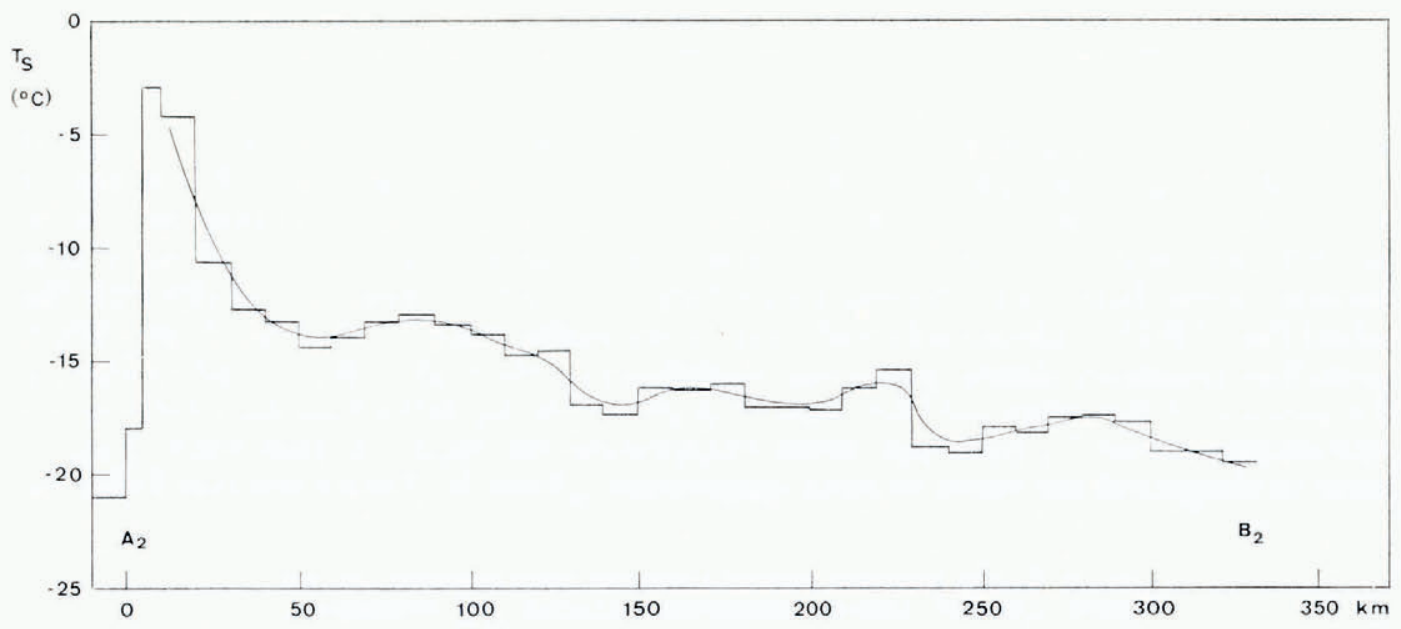

Fig. 7. North-south profile 22 April 1974.

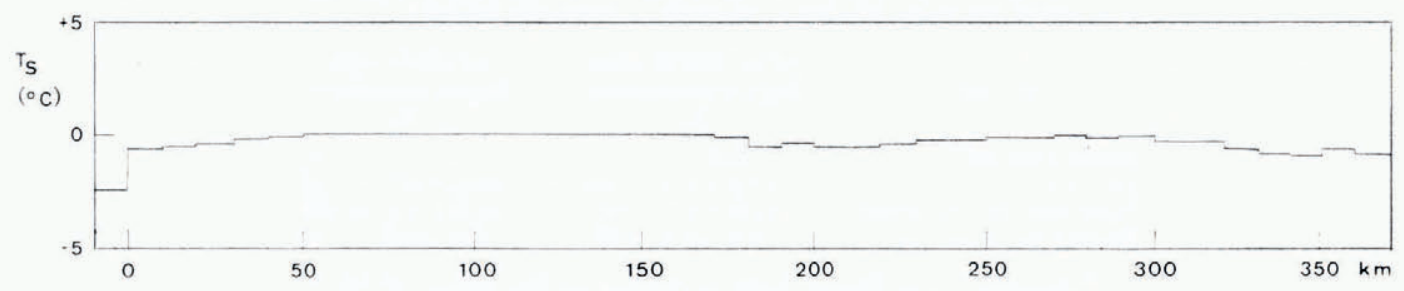

Fig. 8. North-south profile 8 fune 1974 . 


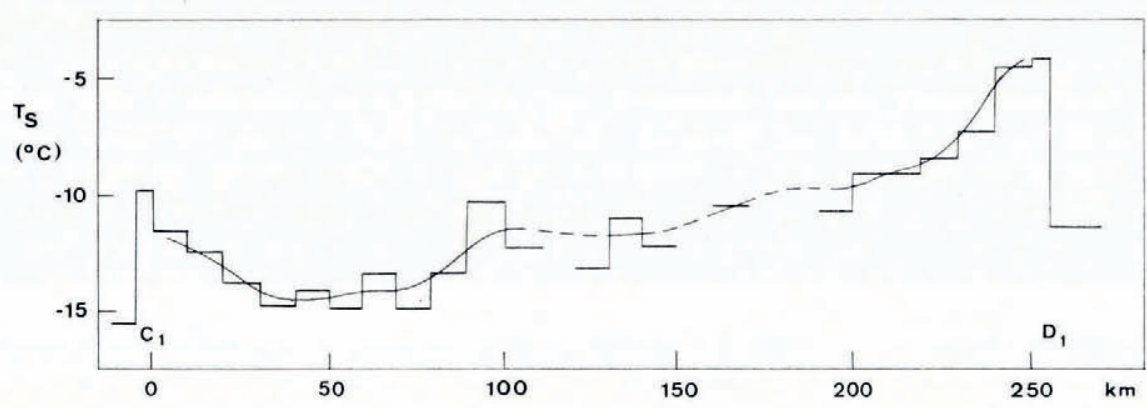

Fig. 9. West-east profile 30 March 1974 (dashed line indicates lack of data due to fog banks).

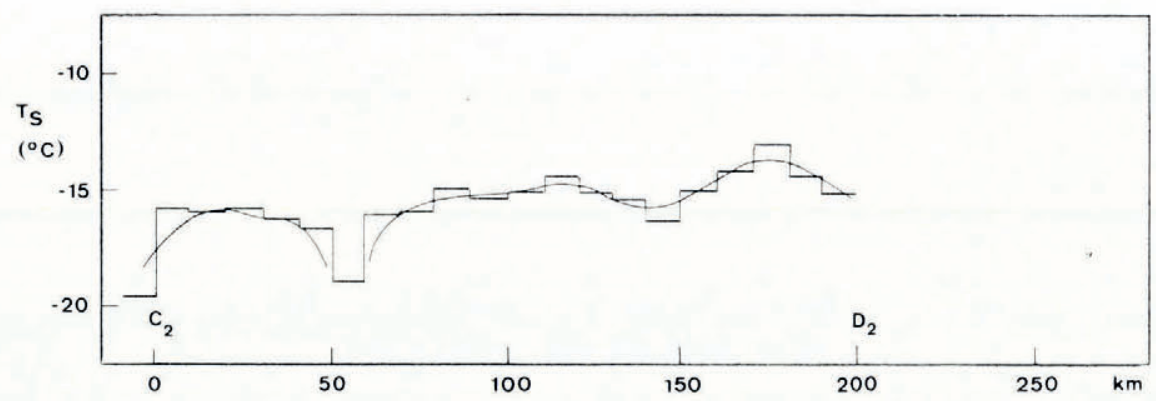

Fig. 10. West-east profile 22 April 1974 (note discontinuity due to cold fast-ice projection after $50 \mathrm{~km}$ ).

using a three-point Gaussian filter. In this procedure the size of the resolution element is increased to Io $\mathrm{km}$, consequently all fluctuations smaller than that disappear. The smoothed profiles and a fortiori the isothermal maps cannot therefore show individual structures of the North Water surface cover, such as leads, areas of open water, or multi-year ice floes, if their diameter is less than $10 \mathrm{~km}$. Auxiliary information on sea-ice distribution on this scale obtained from ERTS-I photographs and visual observations made by the three North Water teams from mountain vantage points was utilized to map the edge of fast ice and to improve the accuracy of the isothermal lines between profiles. For the latter some knowledge of the relationship between ice types and surface temperatures was required. Four types of sea ice could be recognized and linked to mean temperatures (Table I). On the first two flights the

TABle I. Relationship BetWeEn SURface TEMPERAtURES AND ICE TYPES BASED ON ANALOG TEMPERATURE RECORDS AND PHOTOGRAPH STRIPS

The figure in parentheses is the number of samples; the sample size is equal to the basic resolution element, c. $200 \mathrm{~m}$ in length.

$$
\text { Ice type }
$$

Multi-year ice* Fast ice First-year ice (moving) Black nilas (moving)

$$
\text { 3o/3I March } 1974
$$$$
\text { Surface temperature }
$$
${ }^{\circ} \mathrm{C}$

$$
\begin{aligned}
& 22 \text { April } 1974 \\
& \text { Surface temperature } \\
& { }^{\circ} \mathrm{C}
\end{aligned}
$$

$$
\begin{array}{rr}
-28 & (-) \\
-17.7 \pm 1.3(29) \\
-13.8 \pm 1.3(701) \\
-2.6 \pm 0.7(88)
\end{array}
$$
accuracy $\pm \mathrm{I}$ deg. 


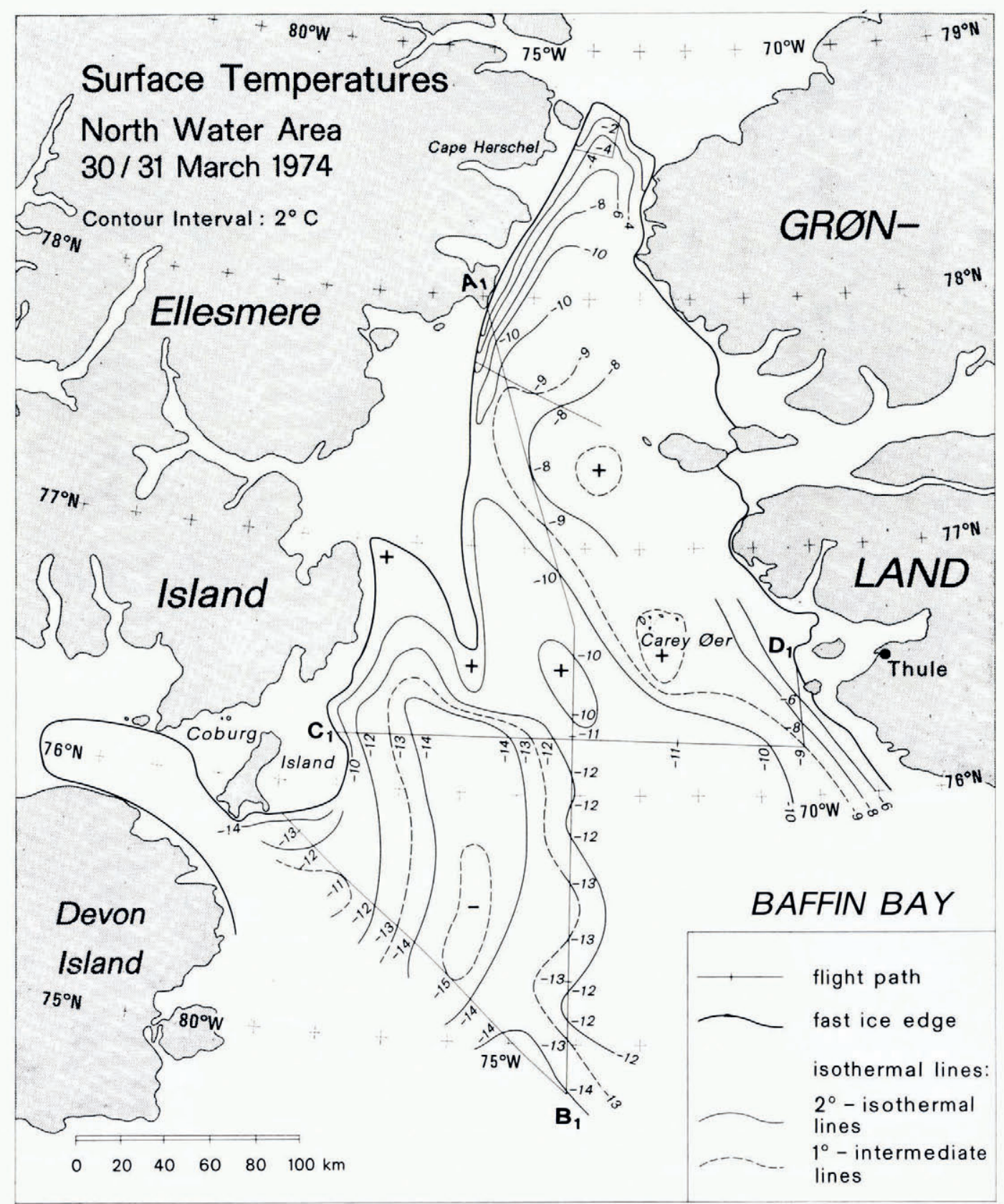

Fig. II. Isothermal map 3o/3I March I974. 


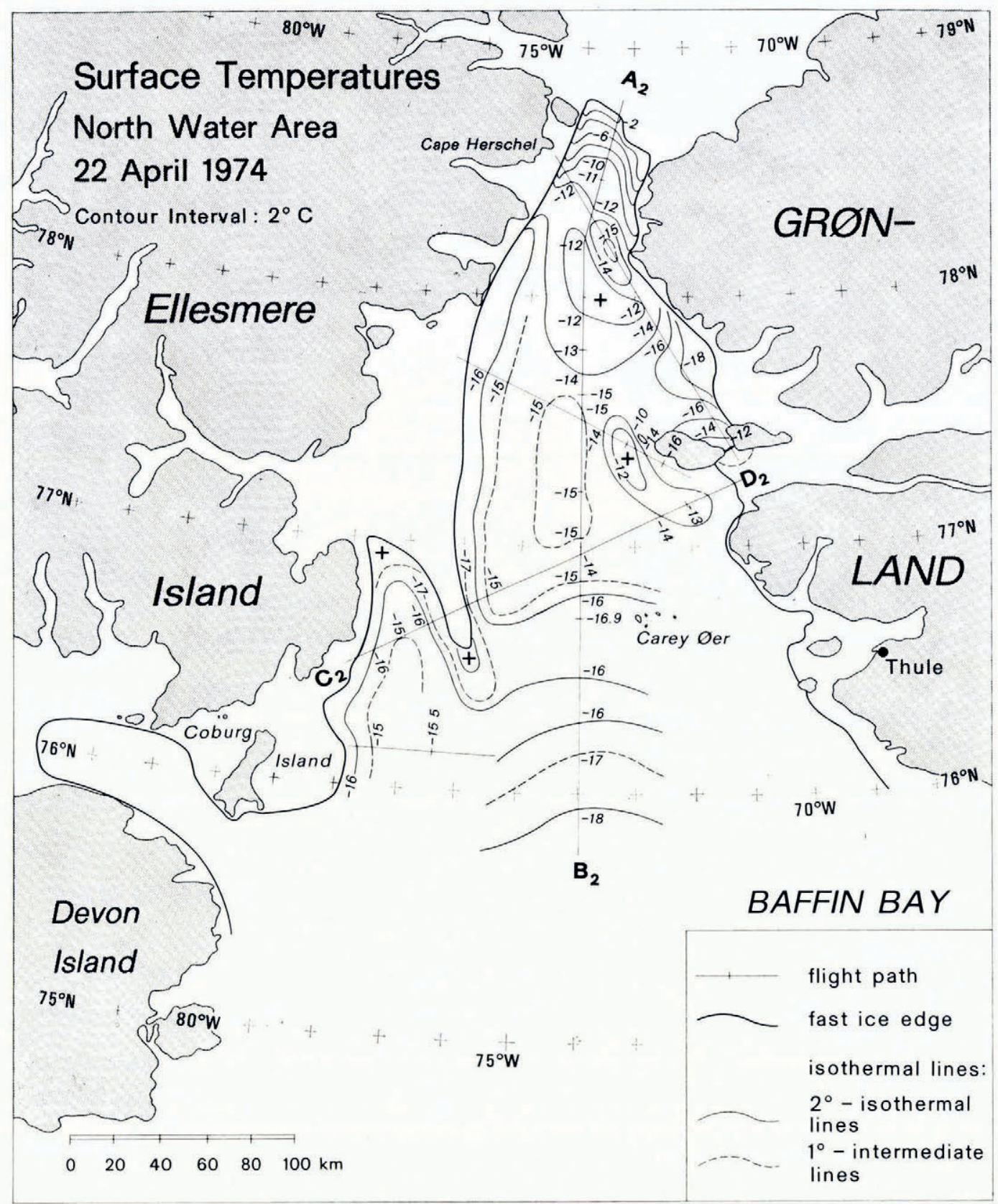

Fig. 12. Isothermal map 22 April 1974. 
surface temperatures differed significantly for the four sea-ice types, but by 8 June (Fig. 8) a melt-water cover obscured these distinctions. Table I indicates that the observed temperature differences correspond to variations in sea-ice thickness. For logistic and safety reasons the ground control to test this idea could only be very limited (Table II). The observed thickness change in fast ice is negligible and corresponds to the small surface temperature difference for this ice type shown in Table I.

TABLE II. ThickNesS OF FAST ICE DURING REMOTE-SENSING Missions The figure in parentheses is the number of measurements.

\begin{tabular}{llrrr} 
& & $30 / 31$ March 1974 & 22 April 1974 \\
Coburg & & $\mathrm{cm}$ & $\mathrm{cm}$ \\
\multirow{3}{*}{ Herschel } & Marina Bay & $143(5)$ & $134(2)$ \\
& north side & Ross Bay & $158(12)$ & $155(12)$ \\
& edge of Kane Basin & $122(9)$ & $122(6)$ \\
& $90(2)$ & $100 \quad(2)$
\end{tabular}

The air temperatures prior to and during flight time (Table III) also affect the surface temperature of the different ice types for a given time and ought to be incorporated in a qualitative way as an additional correction. As already indicated by Table III this is a complex matter. Energy input into the area by air-mass movement, short-term fluctuations of the air temperature resulting from radiation changes (shadows of clouds, zenith angles of the sun) and local wind conditions influence the pattern of the surface temperatures on various scales.

Table III. Mean air temperature at the North Water research STATIONS FOR THE $24 \mathrm{~h}$ PRIOR TO AND DURING REMOTE SENSING MISSIONS

\begin{tabular}{|c|c|c|c|}
\hline & $\underset{{ }^{\circ}}{30}{ }^{\text {March }} 1974$ & $3^{31}$ March 1974 & 22 April 1974 \\
\hline Coburg & -18.5 & -18 & -19 \\
\hline Herschel & -20 & -22 & -18.5 \\
\hline Carey & -12 & -14 & -16 \\
\hline
\end{tabular}

In conclusion there was a definite warming trend from south to north in the North Water area which seemed to become more pronounced throughout the spring season and then rapidly disappeared early in June with the onset of the Arctic summer. Some areas of warmer surface temperatures persisted during the observation period in the north-eastern portion of North Water (Carey Øer, and to the west and north-west of Northumberland Ø), whereas there was consistently a large projection of cold reaching south-eastward from the Mackinson Inlet area. The entrance to Jones Sound (between Devon Island and Ellesmere Island) appears to be an integral part of North Water. Some of these findings must be considered of preliminary nature until confirmed by further remote-sensing work.

\section{Acknowledgements}

This research was supported by the Canadian Government, Department of Supply and Services (contract OSX 4-0og8), the U.S.A. National Science Foundation (grant $\mathrm{CV}-40404 \mathrm{~A} \mathrm{\#} \mathrm{I)} \mathrm{and} \mathrm{the} \mathrm{Schweizerischer} \mathrm{Nationalfonds} \mathrm{zur} \mathrm{Förderung} \mathrm{der} \mathrm{wissenschaftlichen}$ Forschung (grant 2.383.70). The generous provision of flying time and logistic help by the Polar Continental Shelf Project is gratefully acknowledged. For supplying the camera mount and for many useful suggestions, thanks are extended to $\mathrm{Mr}$ Keith Arnold, Division of Glaciology, Department of Environment, Canada. The maps (Figs I I and I2) were drawn by the Kartographisches Institut, Eidg. Technische Hochschule, Zürich. For assistance in the field and helpful discussions in the office the authors are indebted to numerous members of the North Water team. 


\section{REFERENCES}

Haltiner, G. J., and Martin, F. L. 1957. Dynamical and physical meteorology. New York, McGraw-Hill Book Co., Inc.

Kislovskiy, L. D. I959. Opticheskiye kharakteristiki vody i l'da v infrakrasnoy i radiovolnovoy oblasti spektra [Optical characteristics of water and ice in the infra-red and radiowave regions of the spectrum]. Optika $i$ Spektroskopiya, Tom 7, Vyp. 3, p. 31 1-30. [English translation in Optics and Spectroscopy, Vol. 7, No. 3, 1959, p. $20 \mathrm{I}-06$.]

Kondratyev, K. Y. 1965. Radiative heat exchange in the atmosphere. Oxford, etc., Pergamon Press.

Lorenz, D. 1968. Temperature measurements of natural surfaces using infrared radiometers. Applied Optics, Vol. 7, No. 9, p. I 705-10.

Müller, F., and others. 1973. Das North Water Projekt, [by] F. Müller, A. Ohmura, R. Braithwaite. Geographica Helvetica, 28. Jahrg., [Nr.] 2, p. 1 I I -17 .

Ohmura, A. 1972. Ocean-tundra-glacier interaction model. (In Adams, W. P., and Helleiner, F. M., ed. International geography 1972. Papers submitted to the 22nd International Geographical Congress, Canada, .... Montréal, 1972. Toronto and Buffalo, University of Toronto Press, Vol. 2, p. 919-20.)

\section{DISGUSSION}

R. S. Williams, Jr.: First, two statements: A new ERTS receiving station is planned for eastern Canada (probably at Frobisher Bay, Baffin Island, N.W.T.), which will provide frequent direct coverage of the Davis Strait, most of Greenland, and most of Iceland without having to depend on the on-board tape recorder. ERTS-B will have the same orbital parameters as ERTS-I; its tentative launch date is I6 January 1975, and it will image the same area as ERTS-I 9 d later (i.e. in mid-cycle of ERTS-I). Now, a question. What use have you made of NOAA-2 or NOAA-3 data of the study area? NOAA is a weather satellite with a minimum twice-per-day coverage.

F. MÜLLER: We have collected such imagery for $2 \frac{1}{2}$ months but have not found it very useful for this study. We plan isodensitracer scans of ERTS imagery to try to correlate sea ice and open water on the images with aerial thermal infrared surveys.

A. O. Poulin: Do you have a compilation of surface temperatures versus ice type for all the periods of measurement?

MüLlER: Yes, except for the last flight.

W. D. Hibler, III : What sort of correlations do you expect between ERTS images and thermal infrared?

MüLLER: Primarily a qualitative relationship to major sea-ice types to aid interpolation of isothermal lines. 